\title{
Christia vespertilionis plant extracts as novel antiproliferative agent against human neuroendocrine tumor cells
}

\author{
DANIELA HOFER ${ }^{1}$, GERT SCHWACH ${ }^{1}$, NASSIM GHAFFARI TABRIZI-WIZSY ${ }^{1}$, \\ ANTON SADJAK $^{1}$, SONJA STURM ${ }^{2}$, HERMANN STUPPNER ${ }^{2}$ and ROSWITHA PFRAGNER ${ }^{1}$ \\ ${ }^{1}$ Institute of Pathophysiology and Immunology, Medical University of Graz, Graz; \\ ${ }^{2}$ Institute of Pharmacy/Pharmacognosy, University of Innsbruck, Innsbruck, Austria
}

Received December 18, 2012; Accepted January 29, 2013

DOI: $10.3892 /$ or.2013.2367

\begin{abstract}
Neuroendocrine tumors respond poorly to radiation and conventional chemotherapy, hence surgical removal of the neoplastic tissue is still the most effective way of treatment. In an attempt to find new therapeutic plant extracts of Christia vespertilionis $(\mathrm{CV})$ their antitumor potential in human medullary thyroid carcinoma (MTC) and human small intestinal neuroendocrine tumor (SI-NET) cell lines were tested. Proliferation and viability were analyzed using cell counting and WST-1 assay. Apoptosis was determined by microscopy, luminescence assays for caspases $3 / 7$, and expression studies of apoptosis-related genes. CV extracts showed antiproliferative and proapoptotic effects in all MTC and SI-NET cell lines, whereby high growth inhibition was observed by treatment with the ethylacetate-extracts $(\mathrm{CV}-45)$ in tumor cell lines but not in normal human fibroblasts. Furthermore CV-45 treatment resulted in alterations of gene expression of PDCD5, MTDH and TNFRSF10b in MTC as well as in SI-NET cells. The results indicate that Christia vespertilionis could serve as an anticancer therapeutic for treatment of neuroendocrine tumors.
\end{abstract}

\section{Introduction}

Neuroendocrine tumors (NETs) represent rare tumors that are derived from cells of the embryonic neural crest. They account for $\sim 0.5 \%$ of all malignancies and the incidence is $\sim 2 / 100,000$ (1). The ability to secrete hormones and release them into the bloodstream is one characteristic of NET cells. These tumors originate from endocrine glands, whereby their origin and behavior can vary over a wide range. MTCs are calcitonin producing tumors arising from the parafollicular C-cells and occur in $\sim 4-10 \%$ of all thyroid tumors (2). MTCs

Correspondence to: Dr Roswitha Pfragner, Institute of Pathophysiology and Immunology, Medical University of Graz, Heinrichstrasse 31a, A-8010 Graz, Austria

E-mail: roswitha.pfragner@medunigraz.at

Key words: Christia vespertilionis, neuroendocrine tumors, apoptosis, PDCD5, MTDH, TNFRSF10b
(75\%) mainly occur sporadically, but there is also a familial form of MTCs without any associated endocrinopathies (FMTC), in which germline mutations of the 'rearranged during transfection' (RET) proto-oncogene have very often been identified. The remaining $25 \%$ of MTC cases are autosomal dominantly inherited and are combined with other endocrinopathies summarized as multiple endocrine neoplasia (MEN) type 2A or 2B $(3,4)$. SI-NETs, formerly called carcinoids, have their origin in enterochromaffin cells throughout the intestinal tract. They have the ability to secrete and release serotonin into the bloodstream, which can result in flushing, diarrhea, bronchoconstriction and fibrosis, summarized as the carcinoid syndrome (5).

SI-NETs can occur sporadically, but also in a dominantly inherited form associated with multiple endocrine neoplasia type 1 (MEN1), which occurs due to loss-of-function germline mutations of the MEN1 gene. Since these NETs usually have already metastasized when diagnosed, none of the treatment options reported have been found to be effective and the response rate has generally been low (6). As the only curative treatment for NETs is early removal of all neoplastic tissue $(7,8)$ new strategies for the treatment remain crucial. Medicinal herbs are of high interest in anticancer drug research (9-11). Christia vespertilionis, a south-east Asian Fabaceae, is known to exhibit antiplasmodial activity and to increase cytotoxicity in HeLa cells compared to normal human lung cells (12). Triterpenes, alkaloids, fatty acids, phenols, alkanes and long chained alcohols have been identified as main constituents of this plant.

Remarkably, isoquinoline alkaloids, usually typical for Papaveraceae or closely related families, were found in Christia plant extracts. In a previous study, pheophorbid-a, a chlorophyll derivative in Christia vespertilionis plant extracts showed high antiproliferative activity in MTC cells (13). The aim of the present study was to examine the in vitro effects of bioactive agents extracted from Christia vespertilionis in chemo- and radiation-resistant NET cells.

\section{Materials and methods}

Plant material. Specimen of Christia vespertilionis, a southeast Asian Fabaceae, was deposited at the Institute of Pharmacy at the University of Innsbruck. The plant was originally bought 
at a market in Vietnam. Aerial parts of the plant were successively extracted in dichloromethane in a Soxhlet apparatus and four subfractions extracted by petroleum ether (CV-44), ethyl acetate (CV-45), butanol (CV-46) and water (CV-47). Two pure substances, palmitine (CV-48) and corynoxidine (CV-49), were isolated from CV-46. The identity was confirmed by $1 \mathrm{D}$ and 2D NMR spectroscopy and mass spectrometry. Dried extracts were redissolved in dimethyl sulfoxide (DMSO, Sigma-Aldrich, Vienna, Austria) at a concentration of $5 \mathrm{mg} / \mathrm{ml}$ and stored at $-20^{\circ} \mathrm{C}$.

Cell lines and cell culture. The human MTC cell line $M T C$-SK (14), the SI-NET cell line KRJ-I (15) and the normal human fibroblast cell line $H F-S A R$ (Pfragner R, personal communication) were established in our laboratory. MTC-SK and KRJ-I cells were cultured in Ham's F12:M199 medium (1:1) (BioWhittaker; Lonza, Verviers, Belgium) with $10 \%$ fetal bovine serum (FBS) (PAA Laboratories, Pasching, Austria) at an initial cell number of $2 \times 10^{5}$ cells $/ \mathrm{ml}$. Human skin fibroblasts, $H F-S A R$, isolated from a 2-year-old male served as control and were cultured in DMEM (BioWhittaker; Lonza), supplemented with L-glutamine and 10\% FBS (PAA Laboratories, Vienna, Austria) at an initial cell number of $1 \times 10^{5}$ cells $/ \mathrm{ml}$. All cells were cultured at $37^{\circ} \mathrm{C}$ in a humidified atmosphere containing $5 \% \mathrm{CO}_{2}$. Cell lines were Mycoplasma-free, as tested with MycoAlert Mycoplasma detection kit (Lonza, Rockland, ME, USA). For all experiments, cells were cultured without antibiotics.

Cell counting. Cells were counted with the CASY- $1{ }^{\circledR}$ Cell Counter Analyser TTC (Schärfe system; Reutlingen, Germany). $M T C-S K$ as well as $K R J-I$ cells were seeded into 24-well plates at a density of $2 \times 10^{5}$ cells $/ \mathrm{ml}$ and incubated for 24,48 and $72 \mathrm{~h}$, respectively, with DMSO (control) or supplemented with $10 \mu \mathrm{g} / \mathrm{ml}$ of $\mathrm{CV}$ extracts. Cell clusters were pipetted into single cells and each sample was analyzed in triplicate by cell counting.

Cell proliferation. WST-1 cell proliferation reagent (Roche Diagnostics, Vienna, Austria) was used to quantify viability and proliferation in $M T C-S K, K R J-I$ and $H F-S A R$ after CV treatment. Mitochondrial dehydrogenases are able to convert WST-1, a tetrazolium salt, into formazan, which leads to a change of absorbance. $M T C-S K$ and $K R J-I$ cell suspensions were seeded into 24-well plates and incubated with DMSO (control) or $10 \mu \mathrm{g} / \mathrm{ml}$ of plant extracts; then cell viability was measured. After 24, 48 and $72 \mathrm{~h}$ of treatment, cell aggregates were pipetted into single cells. The measurement was carried out according to the manufacturer's protocol. Adherent $H F-S A R$ cells were directly seeded into 96-well plates and cell viability was measured as above. Samples were tested in 6 replicates.

DAPI staining. DAPI (4',6'-diamidino-2 phenylindole) is a fluorochrome that forms fluorescence complexes with doublestranded DNA. Treatment of cells with the fluorescent dye leads to a blue coloring of the nuclei when irradiated at an excitation wavelength of $350 \mathrm{~nm}$. Apoptotic nuclei can be identified by the condensed chromatin gathering at the periphery of the nuclear membrane or a fragmented morphology of nuclear bodies, observed by fluorescence microscopy. Cell pellets of $M T C-S K$ as well as $K R J-I$ cells were resuspended in DAPI (Sigma) solution pursuant to the manufacturer's instructions. The stained cells were pipetted onto glass slides, covered with a cover slip and analyzed under a fluorescence microscope (Leica DM 4000/EL6000; Leica, Wetzlar, Germany). Nuclei that showed clearly condensed and fragmented chromatin were scored as apoptotic.

Caspase-Glo 3/7 assay. To measure the activity of apoptotic key effector caspases 3 and 7, the Caspase-Glo ${ }^{\circledR}$ 3/7 assay (Promega, Mannheim, Germany), which is based on a luminescence reaction, was used. The obtained luminescence signal is proportional to caspase $3 / 7$ activity. In a time period of 5 or $8 \mathrm{~h}$, respectively, CV extract or DMSO was added to the cells. Samples were transferred into white-walled 96-well plates (Nunc ${ }^{\mathrm{TM}}$, Thermo Fisher Scientific, Vienna, Austria). Caspase-Glo 3/7 reagent was added according to the manufacturer's instructions and luminescence of each sample measured with the GloMax ${ }^{\circledR}-$ Multi $^{+}$Microplate Multimode Reader with Instinct ${ }^{\mathrm{TM}}$ (Promega). Medium supplemented with $10 \%$ FBS was used for blank reactions. DMSO treated cells were used as control. Each treatment was measured in triplicate; arithmetic mean and SD were calculated automatically by the GloMax software.

Cell morphology. Effects of CV-45 on cell morphology of treated $M T C-S K$ and $K R J-I$ cells were observed with the Nikon inverted microscope (Eclipse TE 300; Nikon, Tokyo, Japan). $M T C-S K$ and $K R J-I$ cells $\left(2 \times 10^{5}\right.$ cells $\left./ \mathrm{ml}\right)$ were treated with either $10 \mu \mathrm{g} / \mathrm{ml}$ of CV-45 or DMSO (control) and incubated for 24, 48 and $72 \mathrm{~h}$ in 24-well plates. After each incubation day, cell morphology was observed and images were taken (Nikon 12-bit CCD camera, Nikon).

RNA extraction and reverse transcription. MTC-SK and KRJ-I cells $\left(2 \times 10^{5}\right.$ cells $\left./ \mathrm{ml}\right)$ were transferred into cell culture flasks $\left(75 \mathrm{~cm}^{2}\right)$ and incubated for $2 \mathrm{~h}$ with $10 \mu \mathrm{g} / \mathrm{ml}$ of $\mathrm{CV}-45$, or DMSO (control). After incubation, cells were transferred into $50 \mathrm{ml}$ tubes (Sarstedt), and centrifuged for $10 \mathrm{~min}$ at $300 \mathrm{x} \mathrm{g}$; the cell pellets were used for RNA isolation with the TRI Reagent $^{\circledR}$ (Molecular Research Centre, Cincinnati, OH, USA). The concentration of isolated RNA was determined using the Nanodrop (NanoDrop ${ }^{\circledR}$ Spectrophotometer ND-1000, Peqlab Biotechnology $\mathrm{GmbH}$, Erlangen, Germany). Each preparation $(1 \mu \mathrm{g})$ was reverse-transcribed using the High Capacity RNA to cDNA kit (Applied Biosystems, Carlsbad, CA, USA) following the manufacturer's instructions.

Quantitative real-time polymerase chain reaction ( $q$ RT-PCR). The relative gene expression of $M T D H$ (Metadherin, also known as lyric), PDCD5 (programmed cell death 5) and TNFRSF10b (tumor necrosis factor receptor superfamily, member 10b) in CV treated cells in comparison to untreated cells (control) was analyzed. Primers are summarized in Table I. SYBR Green I fluorescence dye (Bio-Rad) was used for detection. IQ Sybergreen Supermix,12.5 $\mu 1$, with $5.5 \mu 1$ RNAse free water and $0.5 \mu \mathrm{l}$ of each forward and reversed primer $(10 \mu \mathrm{M})$ were mixed thoroughly and $6 \mu \mathrm{l}$ cDNA (5 ng/ $\mu \mathrm{l}$ ) of CV-45 treated and untreated MTC-SK and KRJ-I 
Table I. Primer sequences for quantitative RT PCR.

\begin{tabular}{|c|c|c|c|c|c|}
\hline $\begin{array}{l}\text { GenBank } \\
\text { Acc. no. }\end{array}$ & Gene ID & Gene name & Forward primer & Reverse primer & $\begin{array}{l}\text { Product } \\
\text { size (bp) }\end{array}$ \\
\hline NM_178812 & MTDH & Metadherin & CAGATCAGTGCAGGTGAGGA & GGAATTGGTTCCTGGGACTT & 374 \\
\hline NM_004708 & PDCD5 & $\begin{array}{l}\text { Programmed } \\
\text { cell death } 5\end{array}$ & AAAGCACAGGGAAGCAGAAA & GGGCACATAGTCATCCCACT & 275 \\
\hline NM_003842 & TNFRSF10B & $\begin{array}{l}\text { Tumor necrosis } \\
\text { factor receptor } \\
\text { superfamily, } \\
\text { member } 10 \mathrm{~b}\end{array}$ & CACCAGGTGTGATTCAGGTG & CCCCACTGTGCTTTGTACCT & 221 \\
\hline NM_001256799 & GAPDH & $\begin{array}{l}\text { Glyceraldehyde- } \\
\text { 3-phosphate } \\
\text { dehydrogenase }\end{array}$ & AATGCCTTGTCGAAGTCCAG & TCTGTGTCTGCCTTTGTTGG & 236 \\
\hline
\end{tabular}

cells added to the Master mix in PCR tubes. For the calibration curve of each gene of interest, cDNA of pooled RNA (treated + untreated) was added and combined with Master mixes for each gene. The following PCR conditions were used: $95^{\circ} \mathrm{C}$ for $3 \mathrm{~min}, 44$ cycles at $95^{\circ} \mathrm{C} / 10 \mathrm{sec}, 60^{\circ} \mathrm{C} / 45 \mathrm{sec}, 72^{\circ} \mathrm{C} / 40 \mathrm{sec}$, followed by $55^{\circ} \mathrm{C}$ for $10 \mathrm{sec}$ and the condition for the melting curve $\left(55^{\circ} \mathrm{C}-95^{\circ} \mathrm{C}\right.$ for $\left.5 \mathrm{sec}\right)$. Data were normalized using the expression of the housekeeping gene $G A P D H$. Relative gene expression was assessed using the $\triangle \Delta \mathrm{Cq}$-method (16).

Statistical analysis. Medians and SD were calculated using Microsoft Excel software (Microsoft Office, version 2011). A statistical analysis of differences between treated and untreated tumor cells was carried out with a two-tailed unpaired Student's t-test. A P-value $<0.05$ was considered to indicate significance; P-values $<0.01$ indicated 'very significant'. Experimental results are shown in the graphs as mean value \pm standard error of the mean.

\section{Results}

Cell proliferation. The effect of the petroleum ether (CV-44), ethylacetate (CV-45), butanol (CV-46) and water (CV-47) fractions and the two isolated pure substances (CV-48 and CV-49) of Christia vespertilionis on cell-proliferation and cell-viability was tested by cell counting in $M T C$-SK cells. At a concentration of $10 \mu \mathrm{g} / \mathrm{ml}$ all subfractions showed a reduction of cell viability within $72 \mathrm{~h}$ (Fig. 1a). After $72 \mathrm{~h}$ treatment with CV-45, numbers of total viable $M T C$ - $S K$ cells were significantly lower than those treated with DMSO or other fractions. Isolated pure Christia vespertilionis showed very weak inhibition of cell viability; only after $72 \mathrm{~h}$ did CV-48 show decreased number of viable cells as compared to DMSO treated control cells. We obtained the highest inhibition of proliferation with the ethylacetate fraction $\mathrm{CV}-45$ compared to other tested fractions and pure substances. Treatment of $M T C-S K$ as well as $K R J-I$ cells with $10 \mu \mathrm{g} / \mathrm{ml}$ of CV-45 showed significant inhibition of cell growth. As shown in Fig. 1b, the cell number obtained by cell counting of MTC-SK cells after CV-45 treatment compared to control cells (DMSO) was $11.3 \%$ less after $24 \mathrm{~h}, 28.9 \%$ less after $48 \mathrm{~h}$ and $32.5 \%$ less after $72 \mathrm{~h}$ (t-test $\mathrm{p}<0.05)$. The cell number obtained by counting KRJ-I cells (Fig. 1c) after CV-45 treatment was also significantly decreased as compared to control cells. Following CV-45 treatment, total viable cell counts decreased by $11.1 \%$ after 24 h, by $20.8 \%$ after $48 \mathrm{~h}$ and by $29.9 \%$ after $72 \mathrm{~h}$ (t-test $\mathrm{p}<0.01)$.

Cell viability. The potency of $\mathrm{CV}$ plant extracts to reduce cell viability of $M T C-S K$ cells is shown in Fig. 1d. After $48 \mathrm{~h}$ of exposure, we measured a decrease in cell viability with CV-44, CV-45 and CV-47, but not with CV-46 and only very weakly with the isolated pure substances CV-48 and CV-49; after $72 \mathrm{~h}$ of treatment CV-46 and CV-47 as well as CV-48 and CV-49 we did not observe antiproliferative effects; on the contrary, CV-44 and CV-45 showed the highest antiproliferative effects after 48 and $72 \mathrm{~h}$ of exposure $(77 \%$ cell viability after $48 \mathrm{~h}$ and $69 \%$ cell viability after $72 \mathrm{~h}$ with $\mathrm{CV}-44$ compared to control cells and $26 \%$ cell viability after $48 \mathrm{~h}$ and $31 \%$ cell viability after $72 \mathrm{~h}$ with CV-45 compared to control cells). The highest antiproliferative effect was measured for CV-45. As shown in Fig. 1e, cell viability of $M T C-S K$ decreased $21.1 \%$ after $24 \mathrm{~h}$, $31.8 \%$ after $48 \mathrm{~h}$ and $37.4 \%$ after $72 \mathrm{~h}$ exposure to $10 \mu \mathrm{g} / \mathrm{ml}$ of CV-45 when compared to control cells (DMSO). Similarly to $M T C$-SK cells, $K R J-I$ cells were also suppressed by CV-45 fraction (Fig. 1f). After $24 \mathrm{~h}$ of CV-45 treatment $(10 \mu \mathrm{g} / \mathrm{ml})$ cell viability decreased by $\sim 18.3 \%$, after $48 \mathrm{~h}$, significantly by $23.5 \%$ (t-test $\mathrm{p}<0.05$ ) and after $72 \mathrm{~h}$ by $42.8 \%$ compared to DMSO treated cells (control). In human skin fibroblast $H F-S A R$ serving as control cells, the same concentration of CV-45 did not inhibit cell proliferation (Fig. 2).

DAPI-staining. We found morphological changes in MTC-SK as well as in $K R J-I$ cells including chromatin condensation, cell shrinking and apoptotic bodies when cells were treated for 48 and $72 \mathrm{~h}$ with CV-45 (Fig. 3). No significant changes were observed in $M T C$-SK and KRJ-I control cells (DMSO).

Induction of apoptotic pathway. CV-45 treatment increased caspase 3/7 activity in $M T C-S K$ and $K R J-I$ cells within $24 \mathrm{~h}$, which correlated with a decrease in viable cells. An increase 


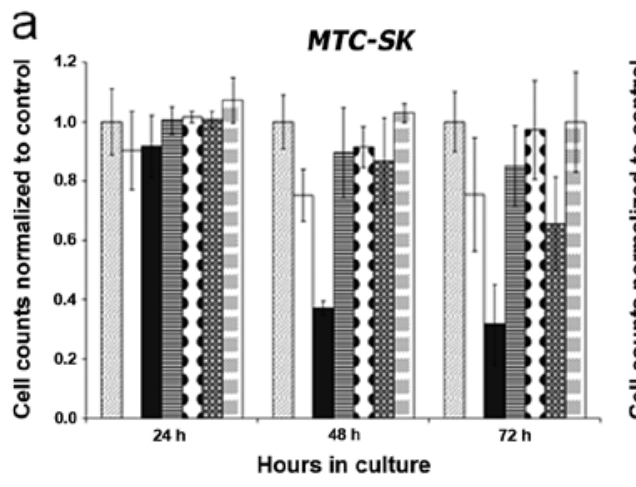

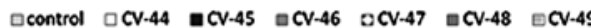

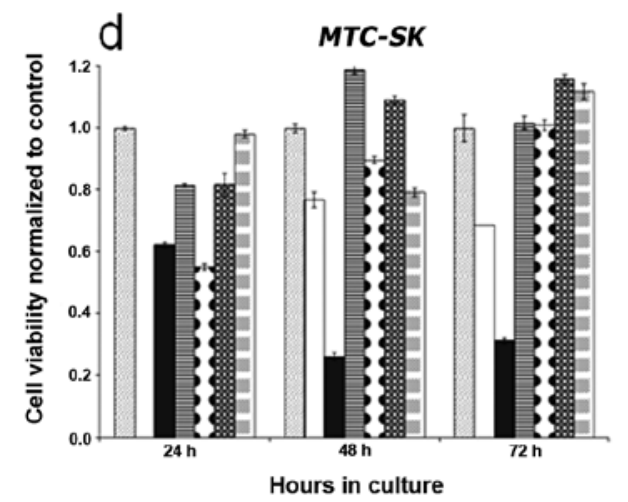

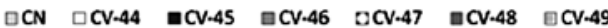

$\mathrm{b}$

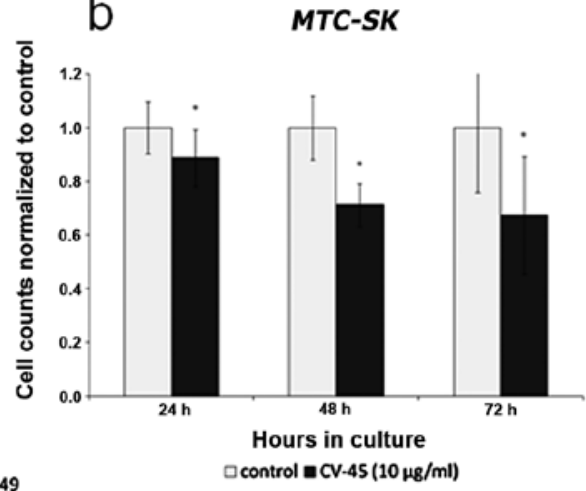

e

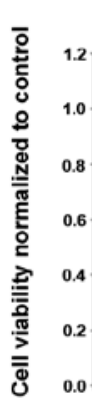

.

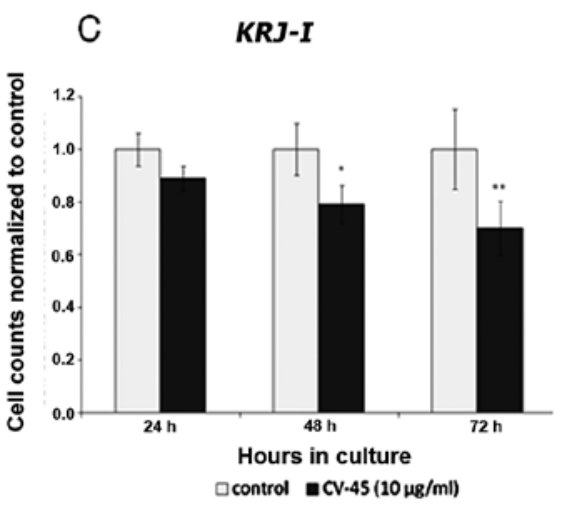

f $\quad K R J-I$

Figure 1. Cell proliferation and viability in $M T C$-SK and $K R J-I$ cells treated with $10 \mu \mathrm{g} / \mathrm{ml}$ Christia vespertilionis subfractions and pure isolated substances Cell proliferation was analyzed by CASY-1 Cell Counter and Analyzer and viability measured by WST-1 cell proliferation assay. (a) Subfractions CV-44 - CV-47 inhibited cell growth after 48 and $72 \mathrm{~h}$ of incubation. Pure isolated substance CV-48 showed inhibition after 48 and $72 \mathrm{~h}$. Treatment with CV-49 showed no growth inhibiting effect in $M T C$-SK cells. (b) Ethylacetate fraction CV-45 showed significant growth inhibiting effects in $M T C$-SK cells after 48 and $72 \mathrm{~h}$ of treatment $(\mathrm{p}<0.05)$. (c) $K R J-I$ cells, treated with $10 \mu \mathrm{g} / \mathrm{ml}$ of CV-45, showed decreased cell proliferation after 24 , significantly after $48 \mathrm{~h}(\mathrm{p}<0.05)$ and highly significantly after $72 \mathrm{~h}(\mathrm{p}<0.01)$. (d) Highest antiproliferative effects were shown after 48 and $72 \mathrm{~h}$ by treatment with CV-44 and CV-45 in $M T C$-SK cells. (e) CV-45 subfraction $(10 \mu \mathrm{g} / \mathrm{ml})$ exhibited antiproliferative effects in $M T C-S K$ cells after 24,48 and $72 \mathrm{~h}$ of treatment. (f) Cell viability in $K R J-I$ cells after treatment with $10 \mu \mathrm{g} / \mathrm{ml}$ of CV-45 subfraction. CV-45 exhibited antiproliferative effects in KRJ-I cells after 24 , significantly after 48 and after $72 \mathrm{~h}$ of treatment, measured by WST-1 assay. ${ }^{*} \mathrm{P}<0.05,{ }^{* *} \mathrm{P}<0.01$.

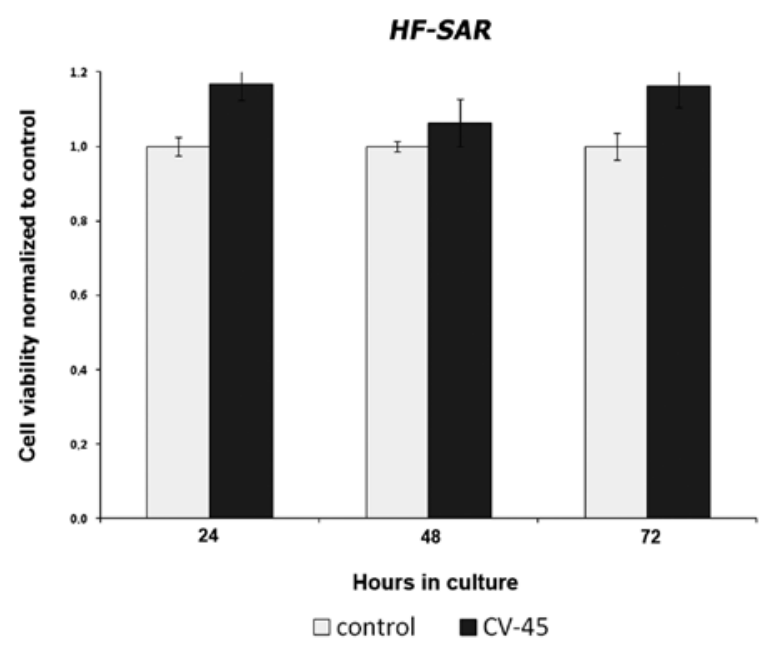

Figure 2. Relative cell viability in human $H F-S A R$ cells after treatment with $10 \mu \mathrm{g} / \mathrm{ml}$ of CV-45 subfraction measured by WST-1 assay. CV-45 exhibited no inhibitory effects in $H F-S A R$ cells after 24,48 or $72 \mathrm{~h}$ of treatment.

of caspase 3/7 activity was no longer evident after 48 and $72 \mathrm{~h}$ of CV-45 treatment, although the amount of viable cells after CV-45 treatment still decreased after 48 and $72 \mathrm{~h}$ (data not shown). After $6 \mathrm{~h}$ of exposure at a concentration of $10 \mu \mathrm{g} / \mathrm{ml}$, the caspase $3 / 7$ activity of CV-45 treated MTC-SK cells was $\sim 21.4 \%$ higher and after $8 \mathrm{~h}$ caspase $3 / 7$ activity nearly doubled (93.1\%) compared to control cells (Fig. 4a). In KRJ-I cells, caspase $3 / 7$ activity had increased by $13.5 \%$ after $2 \mathrm{~h}$ of CV-45 treatment, $17.9 \%$ after $3 \mathrm{~h}, 49.1 \%$ after $4 \mathrm{~h}$ and $61 \%$ after $5 \mathrm{~h}$ CV-45 compared to control cells (Fig. 4b).

Cell morphology in vitro. MTC-SK as well as KRJ-I cells grow in multicellular spheroids. Fig. 6 shows $M T C-S K$ and $K R J-I$ cells after treatment with $10 \mu \mathrm{g} / \mathrm{ml}$ of CV-45 compared to control. Forty-eight hours after adding CV-45 to MTC-SK cells, treated cells showed multicellular aggregates of $\sim 300 \mu \mathrm{m}$ diameter and more single cells were visible, compared to the much larger aggregates $(800-900 \mu \mathrm{m})$ formed by control cells (Fig. 5a and b). In KRJ-I cells, CV-45 treatment also led to reduction of aggregate formation. After $48 \mathrm{~h}$ of CV-45 treatment, multicellular clusters of $K R J-I$ were mostly dissociated into single cells. Aggregates of control cells were twice as large as those of treated cells (Fig. 5c and d).

Gene expression of PDCD5, MTDH and TNFRSF10b. The data on cycles of quantity $\left(\mathrm{C}_{\mathrm{q}}\right.$-value $)$ of the reference gene $G A P D H$ showed stable results in $M T C-S K$, indicating that 

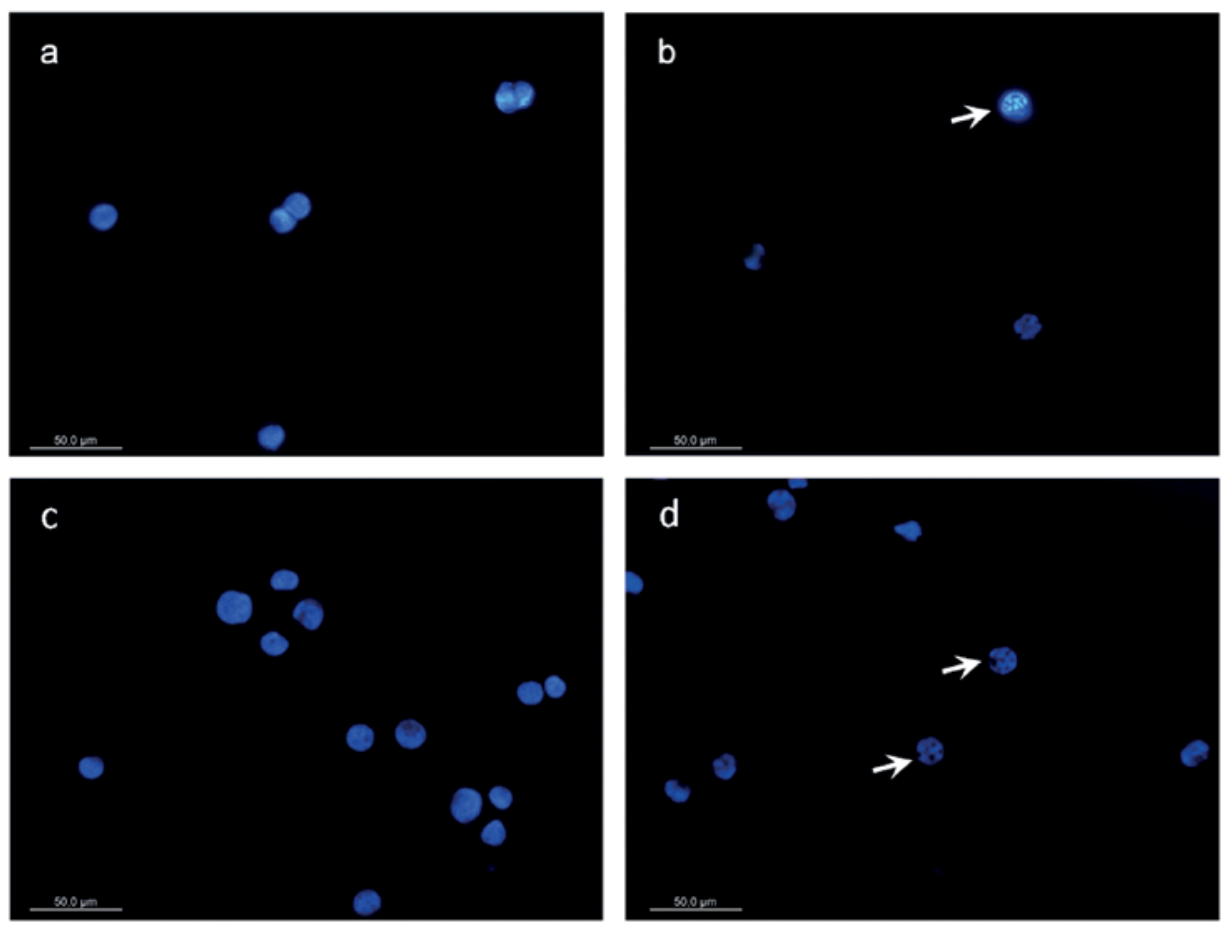

Figure 3. Christia vespertilionis CV-45 induces apoptosis in $M T C-S K$ and $K R J-I$ cells. $M T C-S K$ as well as $K R J-I$ cells were treated with $10 \mu \mathrm{g} / \mathrm{ml}$ of $\mathrm{CV}-45$ or DMSO and stained (DAPI) after 48 and $72 \mathrm{~h}$, respectively. (a) $M T C$-SK control cells after $48 \mathrm{~h}$ (b) apoptotic body in $M T C$-SK after $48 \mathrm{~h}$ of CV-45 treatment (c) KRJ-I control cells after $72 \mathrm{~h}$ (d) apoptotic bodies in KRJ-I after $72 \mathrm{~h}$ of CV-45 treatment. Bar, $50 \mu \mathrm{m}$. (apoptotic bodies are marked with arrows).
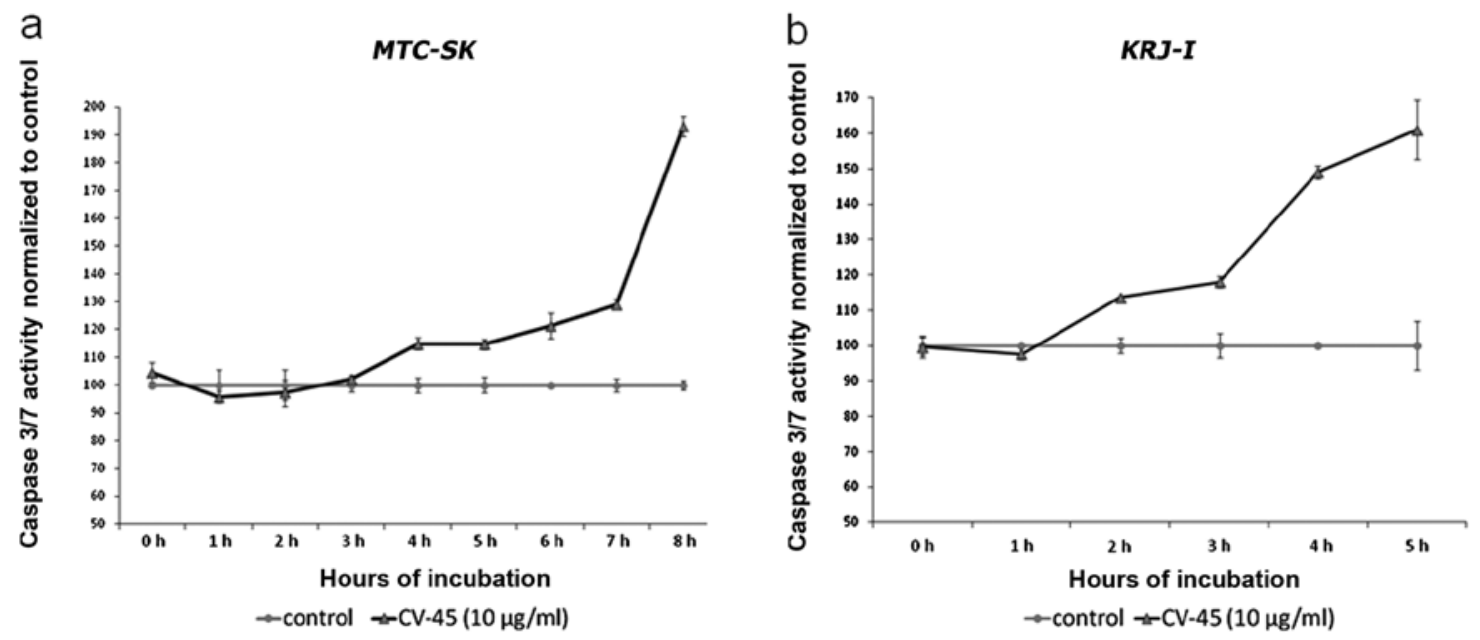

Figure 4. Caspase 3/7 activity after CV-45 treatment in $M T C-S K$ and $K R J-I$ cells and normalized to contol cells. (a) Caspase activity had increased $3 \mathrm{~h}$ after addition of CV-45 in MTC-SK cells and reached the highest level after $8 \mathrm{~h}$. (b) In $K R J-I$ cells, caspase 3/7 activity was already increased after $2 \mathrm{~h}$ of CV-45 treatment.

expression of GAPDH was not influenced by $\mathrm{CV}-45$ treatment (17.96 in CV-45 treated versus 18.01 in control, data not shown). Quantitative RT-PCR showed increased expression of $M T D H$ and downregulation of PDCD5 and TNFRSF10b in CV-45 treated $M T C$-SK cells (Fig. 6a). Although GAPDH gene expression was slightly influenced by CV-45 treatment in $K R J-I$ cells, the gene expression analysis showed that CV-45 treatment lead to downregulation of $M T D H$ and upregulation of PDCD5 gene expression in KRJ-I cells. The expression of $T N F R S F 10 b$ was not significantly altered in KRJ-I cells when treated for $3 \mathrm{~h}$ with CV-45 (Fig. 6b).

\section{Discussion}

The establishment of new treatment options for chemo- and radiation-resistant NETs is essential because of the inefficacy of conventional chemotherapy. Medicinal herbs have come increasingly into the spotlight as complementary medicines. In the present study, we provide a first report of the antitumor activity of plant extracts from Christia vespertilionis, in which the ethylacetate fraction CV-45 showed significant antiproliferative and pro-apoptotic effects in $M T C-S K$ as well as in KRJ-I cells. 

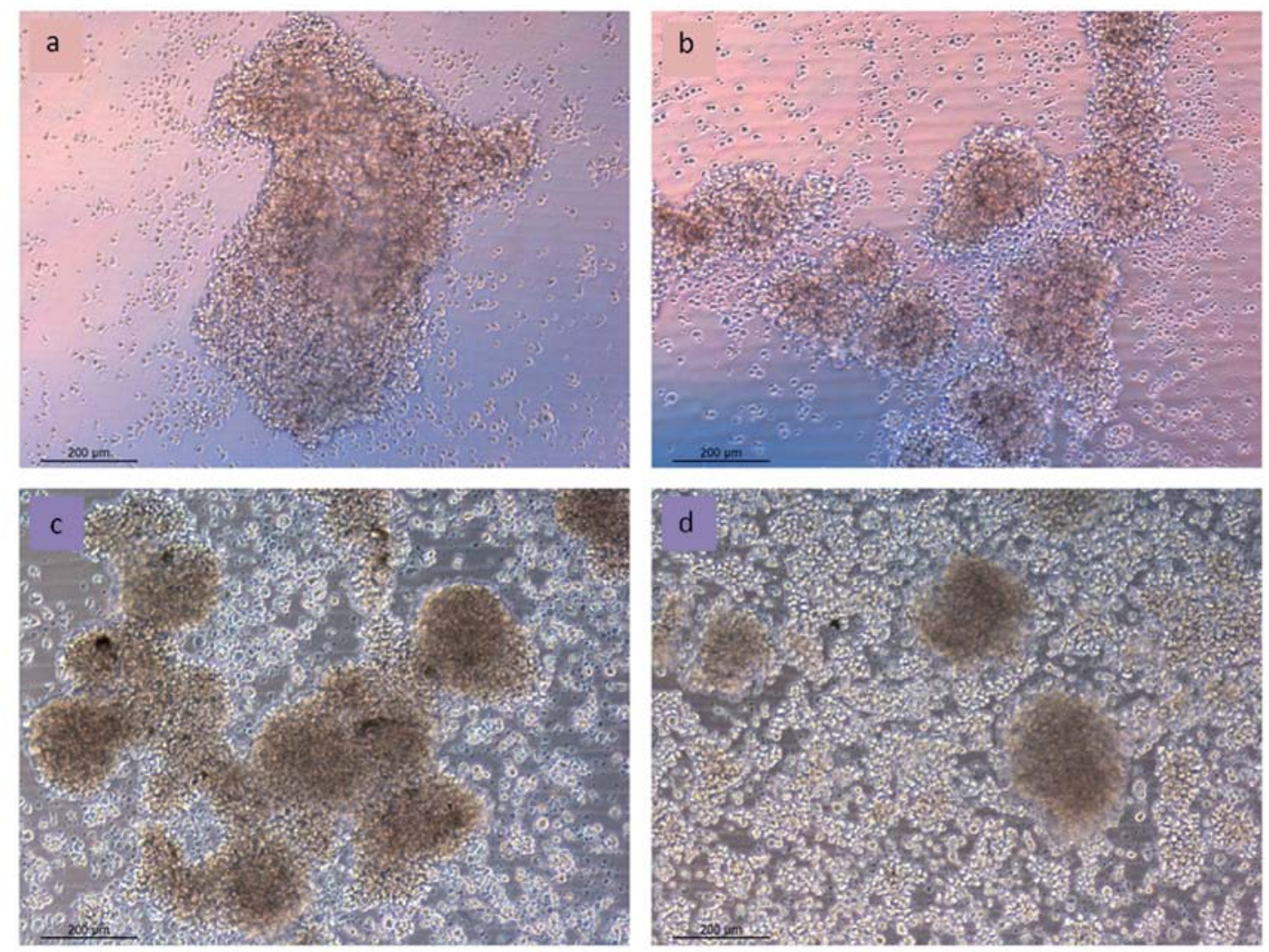

Figure 5. MTC-SK as well as $K R J-I$ cells grow in suspension and form multicellular aggregates. After suspending into single cells, $M T C-S K$ and $K R J-I$ cells were treated with $10 \mu \mathrm{g} / \mathrm{ml} \mathrm{CV-45} \mathrm{or} \mathrm{DMSO} \mathrm{as} \mathrm{control.} \mathrm{(a)} M T C$-SK control after $48 \mathrm{~h}$ of incubation (b) CV- 45 treated $M T C$-SK cells after $48 \mathrm{~h}$ (c) $K R J-I$ control cells after $48 \mathrm{~h}$ (d) CV-45 treated $K R J-I$ cells after $48 \mathrm{~h}$. Compared to control cells, CV-45 treatment for $48 \mathrm{~h}$ lead to reduction of cell aggregates in $M T C-S K$ as well as in KRJ-I cells.
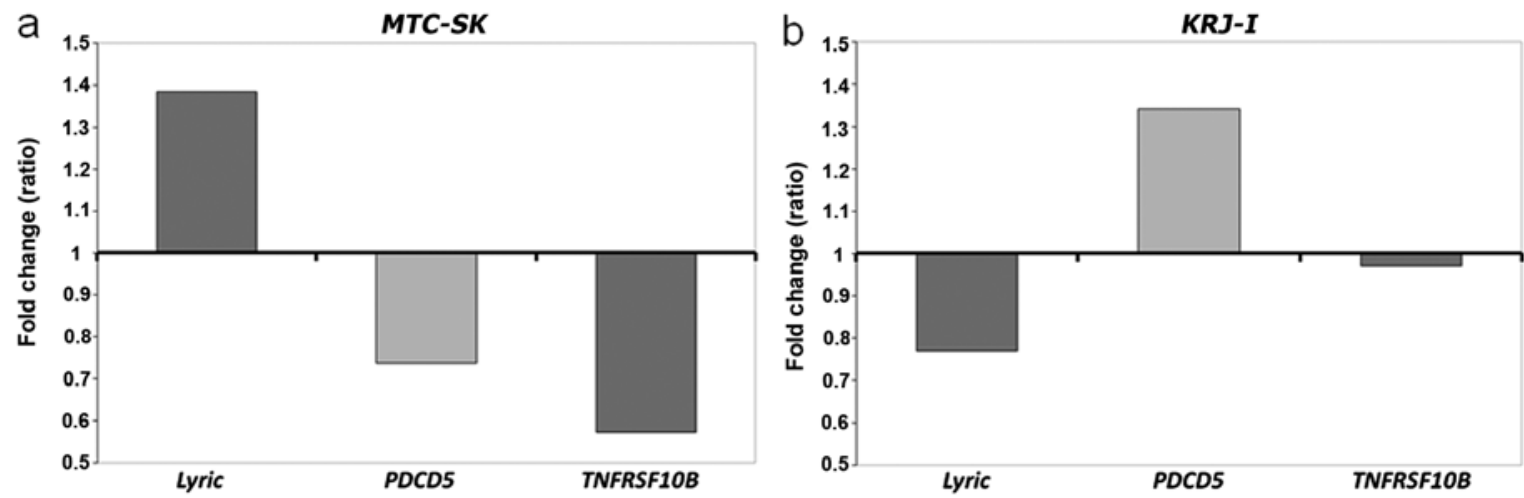

Figure 6. Relative gene expression of $M T D H, P D C D 5$ and TNFRSF10b in CV-45 treated MTC-SK and KRJ-I cells, compared to control cells (DMSO). (a) $M T C$-SK cells, treated for $2 \mathrm{~h}$ with $10 \mu \mathrm{g} / \mathrm{ml}$ of CV-45, showed increased relative gene expression of $M T D H$ and decreased expression of PDCD5 and $T N F R S F 10 b$, compared to control. (b) In CV-45 treated KRJ-I cells, gene expression of $M T D H$ and TNFRSF10b was downregulated and PDCD5 upregulated, when compared to control. $K R J-I$ cells were treated for $3 \mathrm{~h}$ with $10 \mu \mathrm{g} / \mathrm{ml}$ of CV-45 or DMSO as control.

It is known that many chemotherapeutic agents are able to induce apoptosis in cancer cells, as with sorafenib or 5 -fluorouracil for human hepatoma cells $(18,19)$. One goal in the establishment of new therapies against NETs is to define substances that have the ability to trigger anticancer effects and to induce apoptosis specifically in tumor cells, but not in normal cells.

In the human fibroblasts (HF-SAR) tested, the same concentration of CV-45 $(10 \mu \mathrm{g} / \mathrm{ml})$ as used for tumor cells did not inhibit proliferation, suggesting that the composition of this fraction does affect tumor cells specifically. Moreover, bioactive ingredients of Christia vespertilionis extracts, only some of which have been identified to date, look like good candidates for further evaluation. The $\mathrm{CV}$ plant extracts were resolved in DMSO, which is often discussed to be cell toxic. However, Da Violante et al showed, DMSO can be used as solvent at even higher concentrations, up to $10 \%$, without significant cell damage (17). 
The tendency of MTC as well as SI-NETs to grow in multicellular aggregates when cultured in vitro may be evidence for the resistance of NETs to conventional chemo- and radiation therapies $(20,21)$. As reported by Pfragner et al (15), both $M T C-S K$ as well as KRJ-I cells grow in multicellular spheroids. To optimize treatments for MTCs and carcinoid cells, these cell clusters must be dissociated into single cells to make them more accessible to chemotherapeutics. Treatment of MTC-SK and KRJ-I cells with CV-45 showed only weak effects on disruption of cellular aggregates. This may be due to the low concentration of the plant extract in contrast to the pure substance. It should be noted that we do not yet know whether this spheroid destroying effect could also be achieved by other components.

Many chemotherapeutic drugs degrade tumor cells by activating cascades of reactions that generally result in apoptosis. The induction of apoptosis follows a very complex pathway involving many cell proteins. Caspases 3 and 7 are known to be proteases inducing and activating proteins responsible for cell fragmentation and cell shrinking. Further, an evaluation of the activity of caspase $3 / 7$ is a meaningful method to identify induction of apoptosis. The natural compounds of CV-45 showed strong evidence of triggering apoptosis in NET cells. Within $24 \mathrm{~h}$ of CV-45 treatment, caspase $3 / 7$ activity was increased in $M T C-S K$ as well as in $K R J-I$ cells, but no longer after 48 and $72 \mathrm{~h}$. When compared to cell viability, these results correlate within $24 \mathrm{~h}$ of CV-45 treatment, with a decrease in cell counts compared to an increase of caspase 3/7 activity, but no longer correlate after 48 and $72 \mathrm{~h}$. We know accordingly that caspase 3 activation is an early-stage event in apoptosis; thus, this could be the reason why a significant decrease in cell viability and proliferation occurred later than caspase 3/7 activation. The apoptotic potential of CV-45 was also evident in the formation of apoptotic bodies that were observed with fluorescence microscopy after DAPI staining. Nucleic aberrations, manifested in chromatin condensation and nucleic shrinking, were determined in $M T C-S K$ as well as in $K R J-I$ cells, confirming the apoptosis inducing effect of Christia vespertilionis plant extracts.

The object of the present study was also to examine the effects of CV-45 treatment on the relative gene expression of MTDH, PDCD5 and TNFRSF $10 b$ in MTC-SK and KRJ-I cells. We found these genes to be expressed in our cell lines and their expression was altered after treatment. Proteins encoded by the genes PDCD5, MTDH and TNFRSF1Ob are known to be involved in programmed cell death. PDCD5 protein is believed to participate in regulation of apoptosis. Its expression was downregulated in gastric tumor tissue as compared to normal gastric tissue. However, when treated with diallyl trisulfide, which induced apoptosis in gastric cancer, $P D C D 5$ expression was upregulated (22). In $K R J-I$ cells, $P D C D 5$ gene expression was also upregulated with $3 \mathrm{~h}$ of treatment with $\mathrm{CV}-45$, in agreement with literature data. Unlike gene expression in KRJ-I, PDCD5 gene expression was downregulated in $M T C-S K$ with $2 \mathrm{~h}$ stimulation with apoptosis inducing CV-45. This result could possibly be related to insufficient incubation time with $\mathrm{CV}-45$ in these cells. Altered expression of PDCD5 in MTC-SK occurred also in $M T C$ - $S K$ treated for a longer time with $C V-45$. $M T D H$ is known to have a multifaceted role in cancer progression, taking part in the complex network of oncogenic signaling pathways. It is involved in the processes of proliferation, metastasis, survival, chemoresistance and invasion of tumor cells. Furthermore, it interacts with NF- $\kappa \mathrm{B}$ by binding directly to the p65 subunit of the necrosis factor (23).

The upregulation of $M T D H$ in CV-45 treated MTC-SK cells, might lead to the apoptotic effect by the activation of $\mathrm{NF}-\kappa \mathrm{B} . \mathrm{NF}-\kappa \mathrm{B}$ on its part is known for its anti-apoptotic activity, acting as transcription factor for cell survival genes. In contrast $M T D H$ was downregulated in $K R J-I$. A possible explanation could be that downregulation of $M T D H$ leads to less $N F-\kappa B$ activation and further to an inhibition of the expression of cell survival genes involved in cell death. In the present study, the apoptotic potential of CV-45 was demonstrated via caspase $3 / 7$ activation and fluorescence staining in both $M T C-S K$ and $K R J-I$ cell lines. Besides inhibition of $M T D H$, we suppose the presence of another pathway for CV-45 to activate apoptosis in $M T C$-SK. Hu et al (23) also described a connection between $M T D H$ and tumor necrosis factor-related apoptosis-inducing ligand (TRAIL), which is known to activate TRAIL induced apoptosis via the following pathway: TRAIL binds to TNFRSF10b and activates further proteins, known as FADD and initiator caspase 8 , which thereupon activate effector caspases 3 and 7 and finally apoptosis.

$\mathrm{Hu}$ et al explained that overexpressed $M T D H$ leads to downregulation of TRAIL. Thus, decreased TRAIL could possibly mean less TRAIL-induced apoptosis, suggesting that this probably does not occur in CV-45 treated MTC-SK cells. However, knowing that many proteins, also ones yet unknown, are involved in the complex pathway of apoptosis, explanations can only be vague and speculative. The protein encoded by TNFRSF10b gene is a receptor that is also known as death receptor 5 (DR 5), containing a death domain (DD). Some parts of this receptor interact with TRAIL (24), whereas FADD binds with its DD at the DD of TNFRSF10b resulting in formation of the death-inducing signaling complex (DISC). Further, it recruits caspase 8 to DISC, engaging the caspase cascade to induce apoptosis (25). It seems that TNFRSF10b is selectively expressed in cancer cells and may induce TRAILinduced apoptosis in cancer cells (26).

Overexpression of TNFRSF10b led to significant activation

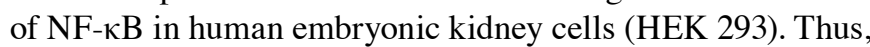
TNFRSF10b was involved in both induction of apoptosis and activation of NF- $\mathrm{BB}(27)$. The downregulation of TNFRSF10b in CV-45 treated $M T C$-SK cells remains to be clarified. In KRJ-I cells, TNFRSF10b gene expression was not significantly altered when compared to control cells. Chaudhary et al showed that overexpression of TNFRSF10b induced apoptosis in mammalian cells via a caspase-dependent mechanism (27). Although caspases 3 and 7 were activated after CV-45 treatment in $M T C-S K$ and $K R J-I$ cells, there was no significant upregulation of TNFRSF10b, but quite the opposite. These results lead to the conclusion that apoptosis might not be induced by the TRAIL/TNFRSF10b mechanism.

The present in vitro study demonstrates the antitumor effects of novel plant derived agents in human neuroendocrine tumor cells. The ethyl acetate fraction of Christia vespertilionis (CV-45) had an antiproliferative and pro-apoptotic effect in MTC cells as well as in SI-NET cells. Fibroblasts were not impaired, indicating a lack of side effects. The in vitro effects of 
the selected plant-derived compounds suggest potential clinical effects in patients with neuroendocrine tumors.

\section{Acknowledgements}

The authors thank Eugenia Lamont for editing the manuscript. This work was supported by the Jubilee Fund of the Austrian National Bank (Project no. 14394), The Franz Lanyar Foundation (Project no. 357), Stadt Graz Wissenschaft, and Land Steiermark Wissenschaft and Forschung.

\section{References}

1. Taal BG and Visser O: Epidemiology of neuroendocrine tumors. Neuroendocrinology 80 (Suppl 1): 3-7, 2004.

2. Saad MF, Ordonez NG, Rashid RK, Guido JJ, Hill CS Jr, Hickey RC and Samaan NA: Medullary carcinoma of the thyroid. A study of the clinical features and prognostic factors in 161 patients. Medicine 63: 319-342, 1984.

3. Vitale G, Caraglia M, Ciccarelli A, Lupoli G, Abbruzzese A, Tagliaferri $\mathrm{P}$ and Lupoli G: Current approaches and perspectives in the therapy of medullary thyroid carcinoma. Cancer 91: 1797-1808, 2001.

4. Eng C and Mulligan LM: Mutations of the RET proto-oncogene in the multiple endocrine neoplasia type 2 syndromes, related sporadic tumors, and Hirschsprung disease. Hum Mutat 9: 97-109, 1997.

5. Modlin IM, Kidd M, Latich I, Zikusoka MN and Shapiro MD: Current status of gastrointestinal carcinoids. Gastroenterology 128: 1717-1751, 2005.

6. Scheuba C, Kaserer K, Weinhausl A, Pandev R, Kaider A, Passler C, Prager G, Vierhapper H, Haas OA and Niederle B: Is medullary thyroid cancer predictable? A prospective study of 86 patients with abnormal pentagastrin tests. Surgery 126: 1089-1095, 1999.

7. Orlandi F, Caraci P, Mussa A, Saggiorata E, Pancani G and Angeli A: Treatment of medullary thyroid carcinoma: an update. Endocr Relat Cancer 8: 135-147, 2001.

8. Modlin IM, Latich I, Kidd M, Zikusoka M and Eick G: Therapeutic options for gastrointestinal carcinoids. Clin Gastroenterol Hepatol 4: 526-547, 2006

9. Li ZX, Sturm S, Stuppner H, Schraml E, Aguiriano Moser V, Siegl V and Pfragner R: The dichloromethane fraction of Stemona tuberosae Lour inhibits tumor cell growth and induces apoptosis of human medullary thyroid carcinoma cells. Biologics 1: 455-463, 2007.

10. Li ZX, Sturm S, Svejda B, Höger H, Schraml E, Ingolic E, Siegl V, Stuppner H and Pfragner R: Anticancer activity of novel extracts from Cautleya gracilis (Smith) Dandy: Apoptosis in human medullary thyroid carcinoma cells. Anticancer Res 28 : 2705-2714, 2008.

11. Rinner B, Li ZX, Haas H, Siegl V, Sturm S, Stuppner H and Pfragner R: Antiproliferative effects of Uncaria tomentosa in human medullary thyroid carcinoma cell. Anticancer Res 29: 4519-4528, 2009.

12. Nguyen-Pouplin J, Tran Ho, Tran Hu, Phan TA, Dolecek C, Farrar J, Tran TH, Caron P, Bodo B and Grellier P: Antimalarial and cytotoxic activities of ethnopharmacologically selected medicinal plants from South Vietnam. J Ethnopharmacol 109: 417-427, 2007
13. Strasser M: Phytochemische Untersuchung von Christia vespertilionis. Diploma thesis, University of Innsbruck, 2010.

14. Pfragner R, Höfler H, Behmel A, Ingolic E and Walser V: Establishment and characterization of continuous cell line MTC-SK derived from a human medullary thyroid carcinoma. Cancer Res 50: 4160-4166, 1990.

15. Pfragner R, Wirnsberger G, Niederle B, Behmel A, Rinner I, Mandl A, Wawrina F, Luo J-S, Adamiker D, Höger H, Ingolic E and Schauenstein K: Establishment of a continuous cell line from a human carcinoid of the small intestine $(K R J-I)$. Int J Oncol 8: 513-520, 1996.

16. Pfaffl MW: A new mathematical model for relative quantification in real-time RT-PCR. Nucleic Acids Res 29: 2002-2007, 2001.

17. Da Violante G, Zerrouk N, Richard I, Provot G, Chaumeil JC and Arnaud P: Evaluation of the cytotoxicity of dimethyl sulfoxide (DMSO) on Caco2/TC7 colon tumor cell cultures. Biol Pharm Bull 25: 1600-1603, 2002.

18. Li ZD, Liu Y, Liao Y and Zuo GQ: Sorafenib and octreotide combination therapy can inhibit proliferation of and induce apoptosis in human hepatoma cells. Zhonghua Gan Zang Bing Za Zhi 20: 126-130, 2012 (in Chinese).

19. Cao Z, Liao L, Chen X, Lan L, Hu H, Liu Z, Chen L, Huang S and $\mathrm{Du} \mathrm{J}$ : Enhancement of antitumor activity of low-dose 5 -fluorouracil by combination with fuzheng-yiliu granules in hepatoma 22 tumor-bearing mice. Integr Cancer Ther: Jul 12, 2012 (Epub ahead of print).

20. Yang KP, Liang YF and Samaan NA: Intrinsic drug resistance in a human medullary thyroid carcinoma cell line: association with overexpression of mdr1 gene and low proliferation fraction. Anticancer Res 11: 1065-1068, 1991.

21. Carlomagno F, Salvatore D, Santoro M, de Franciscis V, Quadro L, Panariello L, Colantuoni V and Fusco A: Point mutation of the RET protooncogene in the TT human medullary thyroid carcinoma cell line. Biochem Biophys Res Commun 207: 1022-1028, 1995.

22. Yang YH, Zhao M, Li WM, Chen YY, Kang B and Lu YY: Expression of programmed cell death 5 gene involves in regulation of apoptosis in gastric tumor cells. Apoptosis 11: 993-1001, 2006.

23. Hu G, Wei Y and Kang Y: The multifaceted role of MTDH/AEG-1 in cancer progression. Clin Cancer Res 15: 5615-5620, 2009.

24. Zhuang L, Lee CS, Scolyer RA, McCarthy SW, Zhang XD, Thompson JF, Screaton G and Hersey P: Progression in melanoma is associated with decreased expression of death receptors for tumor necrosis factor-related apoptosis-inducing ligand. Hum Pathol 37: 1286-1294, 2006.

25. Thomas LR, Bender LM, Morgan MJ and Thorburn A: Extensive regions of the FADD death domain are required for binding to the TRAIL receptor DR5. Cell Death Differ 13: $160-162,2006$.

26. Sheikh MS, Burns TF, Huang Y, Wu GS, Amundson S, Brooks KS, Fornace AJ Jr and El-Deiry WS: p53-dependent and -independent regulation of the death receptor KILLER/ DR5 gene expression in response to genotoxic stress and tumor necrosis factor alpha. Cancer Res 58: 1593-1598, 1998.

27. Chaudhary PM, Eby M, Jasmin A, Bookwalter A, Murray J and Hood L: Death receptor 5, a new member of the TNFR family, and DR4 induce FADD-dependent apoptosis and activate the NFKB pathway. Immunity 7: 821-830, 1997. 